\title{
ANALYSIS AND DETERMINATION OF POSITION BATTALION COMMANDER AAL METHOD WITH PERSONALITY AND METHODS DEMATEL PAPI KOSTICK ANALYTIC NETWORK PROCESS (DFANP)
}

\author{
Didit Herdiawan, Agus Setiadji, Avando Bastari, Adi Bandono \\ Indonesian Naval Technology College, STTAL \\ Bumimoro-Morokrembangan, Surabaya 60187, Indonesia
}

\begin{abstract}
Indonesian Naval Academy ( $A A L)$ is the educational institution that serves to educate Navy officer cadets into future leaders of the Navy to support the main tasks of the Navy in the future. Battalion Commander is a very important position in the organizational structure of the Naval Academy Midshipman educate. In military Commander Regulation no.138/XII/2011 confirms the necessity of each military personnel has soft and hard competencies. Therefore, this study focuses on the analysis and determination of criteria for the post of Batalyon commander of Naval Academy, includes soft and hard competencies and personality using PAPI Kostick, DEMATEL, ANP to get the best commander that is able to realize the basic tasks of the Navy. PAPI Kostick Personality Methods is a personality test on the employment situation. Along with other criteria such as Knowledge, Skills, Health, Phisic test, and Konduite, PAPI Kostick Personality criteria will be examined interrelationships among criteria and sub-criteria therein between using DEMATEL questionnaire. The results of DEMATEL is then drawn into a model of ANP. Furthermore structured questionnaire ANP. Then the results of questionnaires that have been processed, will be used as input in the software Superdecision. The results of the software is the weight of each sub-criteria that can be used in the assessment of the commander of selection . And in the example section assessment, the results of Superdecision software, it can be seen on the ranking of alternative commander's candidate models have added alternative cluster .
\end{abstract}

Keywords : Soft and Hard Competence, PAPI Kostick Personality, DEMATEL, and Analytic Network Process.

\section{INTRODUCTION}

Under Law No. 34 of 2004, the main tasks of the Navy is to uphold the country's sovereignty at sea, marine preserve the territorial integrity of the Republic of Indonesia based on Pancasila and the 1945 Constitution. In carrying out its role and function, the Navy is very dependent on the ability and strength that is supported by the resources available as well as the professionalism of naval soldiers are expected to continue to always be ready to carry out the task. in maintaining the sovereignty of the sea area of the archipelago.

Navy Academy (AAL) is the institution of the Navy which has the function of educating cadets were recruited from high school graduates to be educated with a study period of about 4 years into the future leaders Officer of the Navy to support the main tasks of the Navy in the future. In order to support the basic tasks required $A A L$ educational institutions supporting professional and competent in training and educating human resources in accordance with the organizational structure Midshipman owned. Battalion Commander (Lt) is a very important position in the organizational structure of the Naval Academy Midshipman educate. In the Governor's Decree No. Kep / 310 / XII / 2007 dated December 28, 2007 about the work of the Organization and Procedure Guidelines Navy Academy. Battalion Commander Lt abbreviated is implementing elements of the Regiment in carrying out care for cadets. Danyon is the personnel who act as managers, leaders, decision makers, and 
personnel are fully responsible for the battalion (organization) which leads. The selection process or the determination of personnel who served as a battalion commander during the $A A L$ is only using written tests and interviews dimensionality knowledge, profession, as well as plus skills. So the selection process has not involved the whole factor of hard and soft skills required in the position Battalion Commander AAL._Whereas in the military Perpang No. Perpang 138 / XII / 2011 on Competency Standards Administration Handbook Environment Position in the Armed Forces of Indonesia said that the competencies that must be owned by all soldiers include soft competencies (soft skills) and hard competencies (hard skills). On the basis of this the authors draw up the final task of analyzing and determining the position of Battalion Commander AAL with the aim to create a model selection AAL Battalion Commander position that considers all factors of the hard and soft skills (competencies) that will produce a model that is more objective and relevant.

\section{MATERIALS AND METHODS}

\subsection{DEMATEL}

In this study, the authors use several methods that are considered appropriate to produce a model that is more objective, relevant to the position Battalion AAL. These methods are methods Personality PAPI Kostick, DEMATEL method, Analytic Network Process.PAPI Personality method Kostick is a personality inventory report (self-report inventory), which is composed of 90 pairs of short statement relating to the employment situation, concerns the 20 aspects of personality are grouped into seven (7) fields:leadership, work direction, activity, social nature, work style, temperament, dan followership. Seven field on Kostick PAPI will be subcriteria on PAPI Personality criteria Kostick. In addition, this measure PAPI Kostick role and need of individuals in relation to the work situation, so PAPI Kostick most appropriate when used in personality tests work.

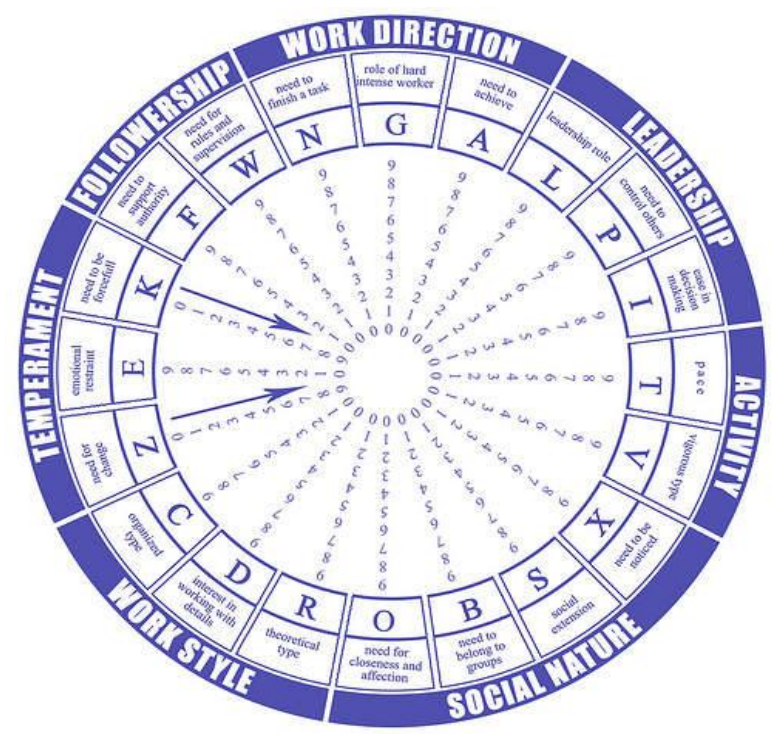

Fig.1 Configuring Disc Dynamics Aspects

While motode DEMATEL is a method that can describe the interrelation between criteria and found the main criteria that represents the effectiveness of a factor, So it can be analyzed causal relationships between factors that are complex in a causal diagram._So DEMATEL method can be used to test whether the model that we created with some of the criteria, it really has the relationship between the criteria with one another before the model criteria are processed with ANP method to find the weights of each criterion. The relationship between the criteria or sub-criteria in DEMATEL depicted in scale value from 0 to 4

Table 1. Scale DEMATEL Method Comparison

\begin{tabular}{|c|c|}
\hline Score & Definition \\
\hline 0 & No influence \\
\hline 1 & Low effect \\
\hline 2 & Medium influence \\
\hline 3 & High effect \\
\hline 4 & Very high effect \\
\hline
\end{tabular}

In preparation DEMATEL method, there are several steps that must be taken (Astria, 2013):

Step 1: Make a direct connection matrix. 
Step 2: Perform normalization of the relationship matrix directly.

$$
\begin{aligned}
& M=k \cdot A \\
& k=\operatorname{Min}\left(\frac{1}{\max _{1 \leq i \leq n} \sum_{j=1}^{n}\left|a_{i j}\right|}, \frac{1}{\max _{1 \leq j \leq n} \sum_{i=1}^{n}\left|a_{i j}\right|}\right)
\end{aligned}
$$

$$
i, j \in\{1,2,3, \ldots, n\}
$$

Stage 3: Getting matrix linkage in total. After getting a direct connection matrix which has been normalized ie the matrix $M$, then the connection matrix in total (eg matrix S) can be obtained from equation (2.3). Where the matrix $I$ is the identity matrix (Chiu et al., 2006).

$$
\begin{aligned}
S & =M+M^{2}+M^{2}+\ldots=\sum_{i=1}^{\infty} M^{i} \\
& =M(I-M)^{-1}
\end{aligned}
$$

Step 4: Calculate the dispatcher group and the receiver group. By using the value of $D R$ and $D R$, where $R$ is the number of columns and $D$ is the number of rows in the matrix $S$. The level of influence and relation to one another to be undefined as seen in equation (2.4), (2.5) and (2.6) (Hori \& Shimizu, 1999)._Some criteria with DR positive value has a greater influence than the other criteria and are assumed to be the main priority, commonly called dispatchers. While the value of DR negative criteria receive a greater influence than the other criteria and are assumed to be the last priority, usually called a receiver._In another section, the value of $D+R$ indicates the relationship between the criteria of the other criteria. So the greater the value of $D+R$ of a criterion means having relationships with other criteria, while criteria with $a \mathrm{D}+\mathrm{R}$ smaller means having a relationship with another smaller criteria. (Seyed, et al., 2005).

$$
\begin{aligned}
& S=\left[S_{i j}\right]_{n x n^{\prime}} \quad i, j \in\{1,2,3, \ldots, n\} \\
& D=\sum_{j=1}^{n} S_{i, j} \\
& R=\sum_{i=1}^{n} S_{i, j}
\end{aligned}
$$

Step 5: Set the threshold value and get a map of impact-diagraph. To obtain a map of impactdiagraph appropriate, the decision maker must set a threshold value for the level of influence._Only a few elements that have a greater influence than the threshold value in the matrix $\mathrm{S}$, can be selected and converted into map-diagraph impact can be seen in Figure map impach diagram, threshold value is determined by decision makers or from people who are experts in how to conduct discussions (Tzeng et al., 2007)._impact-digraph maps can be obtained by plotting the value of $(D+R, D R)$, where the horizontal axis is the value of $D+R$ and the vertical axis is the value of DR (Wu \& Lee, 2007).

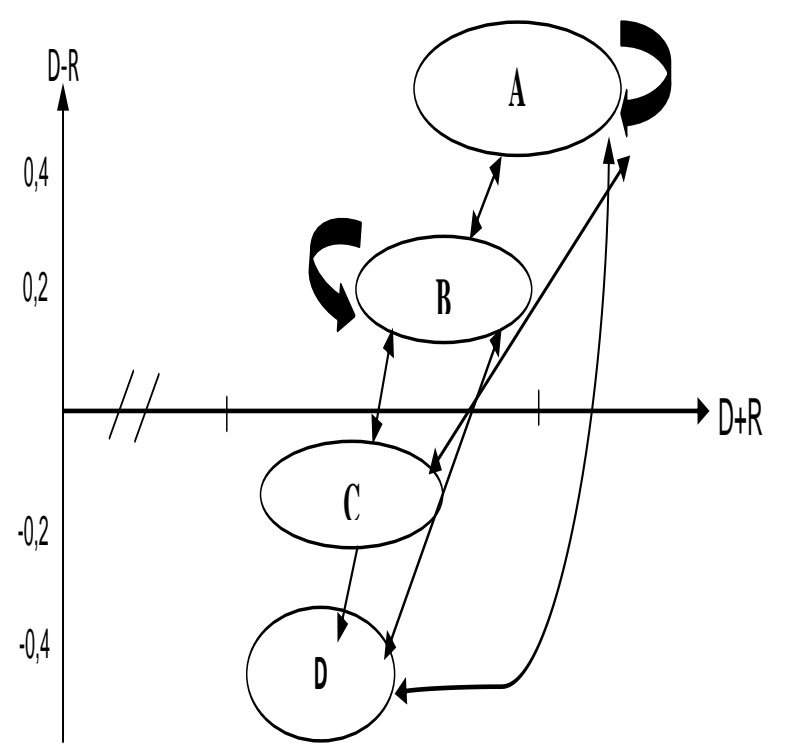

Fig.2 Map Impact-Diagraph

\subsection{Logic Decision.}

If the expert is more than one then do the unification value by using the geometric mean. Geometric mean (geometric mean) is the midpoint between the second opinion or more different 
decision makers. After the test results of each expert questionnaire tested for consistency, then the result is worth it to put together charging through the geometric mean of each of these questions. Geometric mean calculation in this final project with the following formula:

$$
\sqrt[n]{\prod_{i=1}^{n} X_{i}}
$$

Where:

$\mathrm{xi}=$ Decision on the comparison criteria to-

\subsection{PAPI Kostick}

Papi data retrieval Kostick cooperate with the Department of Psychology of the Navy (DISPSIAL) as the competent authorities. From the Department of the Navy Leadership Academy commissioned Captain $(\mathrm{KH})$ Goddess as researchers and decision data. After the $(\mathrm{KH})$ Goddess deepening, Goddess conduct interviews and tests to expert. Data obtained from the results of tests and interviews, then processed in the lab with Assessment Center DISPSIAL Darmo Kali. Following are the results of data processing:

Table 2. Result processing data PAPI Kostick

\begin{tabular}{|c|c|c|c|c|c|c|c|c|c|c|c|c|c|}
\hline & & & 0 & 1 & 2 & 3 & 4 & 5 & 6 & 7 & 8 & 9 & 10 \\
\hline \multirow{3}{*}{ Work Direction } & Need to Finish Task & $\mathrm{N}$ & & & & & & $\mathrm{X}$ & & & & & \\
\hline & Hard Intense Worker & $\mathrm{G}$ & & & & & & & $\mathrm{X}$ & & & & \\
\hline & Need to Achieve & A & & & & & & & $\mathrm{X}$ & & & & \\
\hline \multirow[t]{3}{*}{ Leadership } & Leadership Role & $\mathrm{L}$ & & & & & & & & & $\mathrm{X}$ & & \\
\hline & Need to Control Others & $P$ & & & & & & & $\mathrm{X}$ & & & & \\
\hline & Ease in Decision Making & $\mathrm{I}$ & & & & & & & & $\mathrm{X}$ & & & \\
\hline \multirow[t]{2}{*}{ Activities } & Pace & $T$ & & & & & & $\mathrm{X}$ & & & & & \\
\hline & Vigorous Type & $\mathrm{V}$ & & & & & & & $\mathrm{X}$ & & & & \\
\hline \multirow[t]{4}{*}{ Social Role } & Need to be Noticed & $\mathrm{X}$ & & & & & & $\mathrm{X}$ & & & & & \\
\hline & ocial Extension & $\mathrm{S}$ & & & & & & & $\mathrm{X}$ & & & & \\
\hline & Need to belong to Groups & $B$ & & & & & $\mathrm{x}$ & & & & & & \\
\hline & $\begin{array}{l}\text { Need for Close and } \\
\text { Affection }\end{array}$ & $\mathrm{O}$ & & & & $\mathrm{X}$ & & & & & & & \\
\hline \multirow[t]{3}{*}{ Working Style } & Theoretically type & $\mathrm{R}$ & & & & & & & $\mathrm{X}$ & & & & \\
\hline & $\begin{array}{l}\text { Interest Working with } \\
\text { Details }\end{array}$ & $\mathrm{D}$ & $\mathrm{X}$ & & & & & & & & & & \\
\hline & Organized Type & C & & & & & & & $\mathrm{X}$ & & & & \\
\hline \multirow[t]{3}{*}{ Temperament } & Need for Change & Z & & & & & & $\mathrm{X}$ & & & & & \\
\hline & Emotional Restraint & $\mathrm{E}$ & & & & & $\mathrm{X}$ & & & & & & \\
\hline & Need to be Forceful & $\mathrm{K}$ & & & & & & $\mathrm{X}$ & & & & & \\
\hline \multirow[t]{2}{*}{ Followership } & Need to Support Authority & $\mathrm{F}$ & & & & & $X$ & & & & & & \\
\hline & $\begin{array}{l}\text { Neeed for Rules and } \\
\text { Supervision }\end{array}$ & $\mathrm{W}$ & & $\mathrm{X}$ & & & & & & & & & \\
\hline
\end{tabular}

Mark :

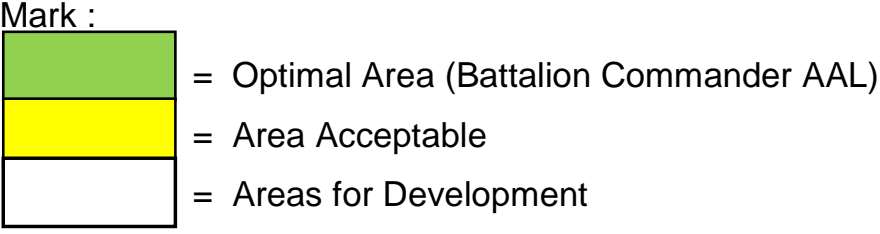

Data processing with methods Decision Making Trial And Evaluation Laboratory
(DEMATEL) consists of several stages (Astria, 2013). The stages are: 
Stage 1: Combining values direct connection matrix which has filled the experts by using the average value.

Step 2: Perform normalization of the relationship matrix directly by multiplying the value in each column with the total value of the sum value of each row.

Stage 3: Getting matrix linkage in total by way of subtracting the value of each column of the identity matrix with matrix normalization results, followed by processing with minverse and MMULT.
Step 4: Calculate the dispatcher group and the receiver group. Group dispatcher and receiver group obtained by determining the value of $D$ and $R$ in advance. The value of $D$ is obtained from the sum of the value of the matrix rows that have been processed with MMULT. While the value of $R$ obtained from the number of columns matrix values after MMULT process.

Step 5: Setting a threshold value (threshold value) and get a map of impact-diagraph.

Table 3. Matrix Results MMULT with Threshold Value

MMUIT

\begin{tabular}{|c|c|c|c|c|c|c|c|c|c|c|c|c|c|c|c|c|c|c|c|c|c|}
\hline & & \multicolumn{7}{|c|}{ Persyartan Kepribadian PAPI Kostick } & \multicolumn{3}{|c|}{ Persyaratan Pengetahuan } & \multicolumn{4}{|c|}{ Persyartann Keterampilan } & \multicolumn{2}{|c|}{ Persyartatan Kesehatan } & \multicolumn{2}{|c|}{ Persyartatan Kessmapptaan } & \multirow{2}{*}{\begin{tabular}{|l|} 
Performance \\
Kondite \\
\end{tabular}} & \multirow[b]{2}{*}{ D } \\
\hline & & irtition. & leadersip & Aduity & Socoll havere & sove & Temper & Followe & kentrann & Prokei & 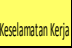 & Peragsilanan & Komnolasi & Bingegis & |exel hromasi & eshetatan Fisk $\mid x$ & 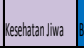 & Datect & Satrece b & & \\
\hline \multirow{7}{*}{$\begin{array}{l}\text { Persy. } \\
\text { Kepribadian } \\
\text { PAPI Kostick }\end{array}$} & Wort tiretion & 0,100157 & 0,137672 & 0,1423353 & 0,1231822 & 0,134239091 & 0,1013993 & 0,0924001 & 0,0839348 & 0,1096986 & 0,11802 & 0,1102151 & 0,1286295 & 0,1207147 & 0,1217272 & 0,1168314 & 0,1142534 & 0,0979332 & 0,0959518 & 0,133138634 & 2,18252836 \\
\hline & leversilip & 0,165294 & 0,1015175 & 0,156247 & 0,133248 & 0,145137589 & 0,1177408 & 0,1144655 & 0,080527 & 0,12232886 & 0,1277537 & 0,126237 & 0,1421071 & 0,1105711 & 0,1150827 & 0,1231304 & 0,1240018 & 0,1001442 & 0,1013366 & 0,146902771 & 2,36267374 \\
\hline & Atuity & 0,14364 & 0,1342828 & 0,0918977 & 0,113855 & , 118443599 & 0,1021554 & 0,1063116 & 0,0786319 & 0,1101746 & 0,102545 & 0,097813 & 0,1286041 & 0,1081183 & 0,1127178 & 0,1143548 & 0,1213473 & 0,099072 & 0,0905481 & 0,1267163 & 10125 \\
\hline & Socid Native & 0,126931 & 0,133952 & 0,1385054 & 0,076411 & 0,121566582 & 0,1126978 & 0,0976264 & 0,082908 & 0,0969357 & 0,0958792 & 0,1016645 & 0,1287067 & 0,0990483 & 0,1068338 & 0,0947872 & 0,1000683 & 0,0860167 & 0,0908683 & 0,123388191 & 2,0238383 \\
\hline & Wor Syle & 0,152724 & 0,156112 & 0,1413525 & 0,1316185 & 0,089526108 & 0,113326 & 0,1072424 & 0,08807 & 0,1079061 & 0,1196957 & 0,1185875 & 0,127252 & 0,1158381 & 0,1170291 & 0,108659 & 0,1160752 & 0,0956655 & 0,0906095 & 0,138484577 & 2,23310227 \\
\hline & Temerarrent & 0,121006 & 0,1156845 & 0,1135242 & 0,1124147 & 16597285 & 0,0642437 & 0,0866861 & 0,082885 & 0,0892704 & 0,091492 & 0,0974087 & 0,1165523 & 0,0913032 & 0,1024009 & 0,0969001 & 0,1139624 & 0,0822678 & 0,0839142 & 0,111460373 & 1,89037363 \\
\hline & Fillowersip & 0,116482 & 0,111275 & 0,1191501 & 0,1019988 & 0,115828408 & 0,0920825 & 0,0563028 & 0,0701538 & 0,0953321 & 0,0978639 & 0,084266 & 0,1062616 & 0,0847177 & 0,0890635 & 0,0903428 & 0,0942654 & 0,0793018 & 0,0777996 & 0,114150922 & 1,7966 \\
\hline \multirow{3}{*}{$\begin{array}{l}\text { Persy. } \\
\text { Pengetathuan }\end{array}$} & kentratan & 0,14165 & 0,1193957 & 0,130949 & 0,09577 & 0,116662116 & 0,0841221 & 0,096235 & 0,0541898 & 0,1194093 & 0,1050002 & 0,0860071 & 0,1139667 & 0,1115072 & 0,105582 & 0,1105106 & 0,1008274 & 0,0823674 & 0,0938441 & 0,115305502 & 1,98734814 \\
\hline & Protesi & 0,1553 & 0,1474278 & 0,1525952 & 0,1322961 & 0,131032924 & 0,1161802 & 0,1139895 & 0,0982071 & $0,0,844286$ & 0,1268915 & 0,115259 & 0,13821256 & 0,1268879 & 0,1207641 & 0,1163991 & 0,1168354 & 0,1129937 & 0,1108194 & 0,133103734 & 2,3475753 \\
\hline & | keselandatan Keria & 0,139195 & 0,1235684 & 0,1350001 & 0,1163822 & 0,127350041 & 0,0987386 & 0,0902197 & 0,079181 & 0,1126966 & 0,0711385 & 0,0970038 & 0,124442 & 0,0954022 & 0,0963571 & 0,1105452 & 0,0951354 & 0,0858989 & 0,0844042 & 0,122493633 & 2,00605505 \\
\hline \multirow{4}{*}{\begin{tabular}{|l} 
Persy. \\
Keterempilan
\end{tabular}} & Perpasalun & 0,135835 & 0,1210932 & 0,1192403 & 0,1082188 & 0,117572656 & 0,0940694 & 0,0861751 & 0,082202 & \begin{tabular}{|l|l|l|l|l|l|} 
\\
\end{tabular} & 0,0940371 & 0,0620638 & 0,1128114 & 0,0978339 & 0,0887152 & \begin{tabular}{|l|l|}
0,0898057 \\
\end{tabular} & 0,093687 & 0,0847677 & 0,0802013 & 0,107384117 & 1,87594277 \\
\hline & lonnilas & 0,140134 & 0,128705 & 0,126045 & 0,111429 & 0,115651179 & 0,0937773 & 0,0889225 & 0,0800793 & 0,11111363 & 0,1101346 & 0,0961076 & 0,0791132 & 0,10726 & 0,1046616 & 0,086001 & 0,0964169 & 0,0838294 & 0,0823777 & 114 & 1,95936 \\
\hline & sithangyris & 0,11659 & 0,1114504 & 0,0997108 & 0,0960472 & 0,099731334 & 0,0827969 & 0,0781407 & 0,0683305 & 0,109635 & 0,0890983 & 0,0785752 & 0,1166877 & 0,0555222 & 0,0866839 & 0,0875367 & 0,080857 & 0,0772071 & 0,0726208 & 0,107813666 & 1,72526416 \\
\hline & 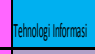 & 0,127699 & 0,131656 & 0,1266308 & 0,1216303 & 0,10558847 & 0,0914079 & 0,0958482 & 0,0783996 & 0,1017629 & 0,103945 & 0,0965044 & 0,1299344 & 0,1005237 & 0,0673601 & 0,085505 & 0,103349 & 0,0908975 & 0,082746 & 0,124515161 & 1,9703 \\
\hline \multirow{2}{*}{\begin{tabular}{|l} 
Persyartan \\
Keseshatan
\end{tabular}} & kesestantisik & 0,155104 & 0,14572 & 0,1565335 & 0,1229824 & 5009 & 0,1007737 & 0,0919206 & 0,0932538 & 0,1288723 & 0,1214164 & 0,1133232 & 0,1266126 & 0,097792 & 0,1051941 & 0,0810567 & 0,1211156 & 0,1242365 & 0,1225575 & 0,130177513 & 2,669 \\
\hline & 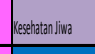 & 0,203027 & 0,197274 & 0,19021 & 0,1755707 & 0,185327939 & 0,1599894 & 0,1359007 & 0,124339 & 0,1695229 & 0,1650512 & 0,1491598 & 0,1825917 & 0,1401303 & 0,1584997 & 0,1632464 & 0,1075034 & 0,1408006 & 0,1222745 & 0,177872272 & 3,04552169 \\
\hline \multirow{2}{*}{\begin{tabular}{|l} 
Persaratan \\
Kesemmaptazan
\end{tabular}} & atreit & 0,135027 & 0,16629 & 0,122007 & 0,1066705 & 0,107933783 & 0,0923653 & 0,0839926 & 0,0871332 & 0,1004132 & 0,099221 & 0,0917784 & 0,1010161 & 0,0888286 & 0,0899504 & 0,1222522 & 0,102377 & 0,059913 & 0,0993546 & 942946 & 1 \\
\hline & 1 attere 1 & 0,12319 & 0,1109855 & 0,1159283 & 0,0884401 & 0,102597323 & 0,0816057 & 0,0797881 & 0,0702093 & 0,0925792 & 0,0946918 & 0,0874127 & 0,0924565 & 0,0873897 & 0,0851707 & 0,1143277 & 0,1039997 & 0,0901011 & 0,0543232 & 0,113859866 & 1,789069944 \\
\hline \multirow[t]{2}{*}{ Performance } & lonotite & 0,128687 & 0,1130671 & 0,1179923 & 0,0875973 & 0,101856119 & 0,1295781 & 0,0852391 & 0,085299 & 0,10388890 & 0,0967757 & 0,0926258 & 0,1017419 & 0,0867047 & 0,0845536 & 0,0962803 & 0,0967305 & 0,0877519 & 0,0832786 & 300527 & 1,85454823 \\
\hline & $R$ & 2,6269 & 2,452187 & 2,499683 & 2,158759 & 2,289464323 & 1,92905 & 1,787316 & 1,57433 & 7, 2,0675 & 2,03025 & 1,904353 & 2,296291 & 1,928281 & 1,954698 & 2,012466 & 2,019038 & 1,760555 & 1,71983 & 2,33547782 & \\
\hline
\end{tabular}

The yellow color indicates the presence of a relationship between the sub-criteria, while gray indicates no relationship between the sub-criteria. The basic relationships that form the model on superdecision program.

\subsection{ANP Data Processing}

Data processing is done after the results of the questionnaire ANP ANP has been distributed to the experts to be filled has been collected back. Total expert on ANP are three people. Questionnaire design using a reference model of the network that has been formed. 


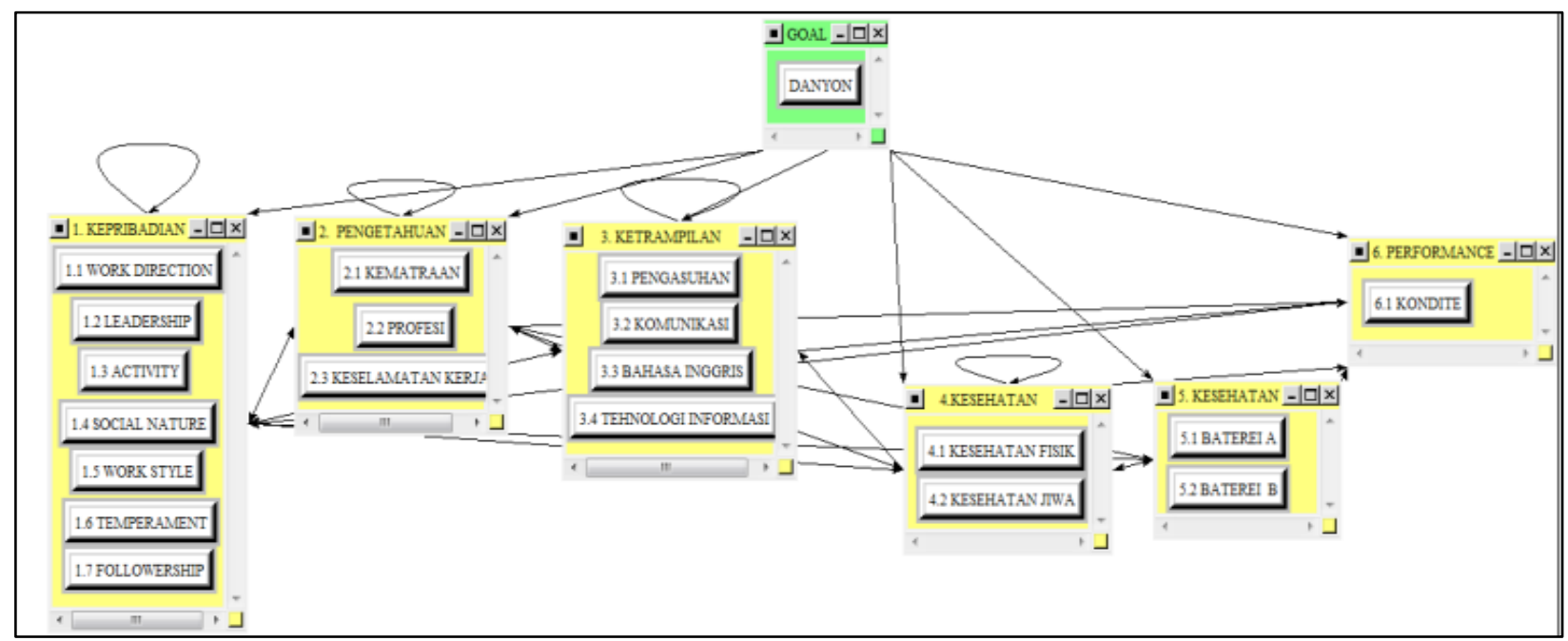

Fig.3 Model Criteria and Sub-Criteria AAL Battalion Commander Position

Questionnaire was developed based on the relationship between both innerdependence subcriteria and outerdependence and relationship preferences between criteria_with the goal (goal) by means of paired comparison between the cluster and the cluster nodes.

This questionnaire aims to find out how much the relationship was based on expert assessment. Requirements or criteria expert on ANP together with requirements or criteria expert on DEMATEL. The numerical values are subjected to the whole comparison is obtained from a comparative scale of 1 to 9 set by Saaty.

\section{RESULT AND DISCUSSION}

\subsection{Calculation Geometric Mean}

Geometric mean (geometric mean) is the midpoint between the second opinion or more different decision makers. After the test results of each expert questionnaire tested for consistency, then the result is worth it to put together charging through the geometric mean of each of these questions. Geometric mean calculation in this final project with the following formula:

$$
\sqrt[n]{\prod_{i=1}^{n} X_{i}}
$$

Mark:

$\mathrm{X} \_\mathrm{i}=$ Decision on the comparison criteria to-
Table 4. Geometric Mean Pairwise Comparison Matrix in the criteria.

\begin{tabular}{|c|c|c|c|c|c|c|}
\hline & \multicolumn{3}{|c|}{ KEPRIBACPENGETAH KETERAn } & \multicolumn{2}{|c|}{ 〈ESAMAP KESEHAT } & ERFORM \\
\hline KEPRIBADIAN & 1,00 & 0,30 & 0,44 & 0,33 & 0,23 & 2,29 \\
\hline PENGETAHUAN & 3,30 & 1,00 & 2,62 & 3,00 & 0,35 & 4,31 \\
\hline KETERAMPILAN & 2,29 & 0,38 & 1,00 & 0,44 & 0,26 & 3,00 \\
\hline KESAMAPTAAN & 3,00 & 0,33 & 2,29 & 1,00 & 0,35 & 4,00 \\
\hline KESEHATAN & 4,31 & 2,88 & 3,91 & 2,88 & 1,00 & 5,24 \\
\hline PERFORMANCE & 0,44 & 0,23 & 0,30 & 0,25 & 0,19 & 1,00 \\
\hline
\end{tabular}

(Source: Data processed by Microsoft Excel)

Table 5. Rounding Geometric Mean Pairwise Comparison Matrix in the criteria.

\begin{tabular}{|l|c|c|c|c|c|c|}
\hline & KEPRIBAD PENGETA & KETERAM & KESAMAPKESEHATAPERFORMA \\
\hline KEPRIBADIAN & 1 & 0 & 0 & 0 & 0 & 2 \\
\hline PENGETAHUAN & 3 & 1 & 3 & 3 & 0 & 4 \\
\hline KETERAMPILAN & 2 & 0 & 1 & 0 & 0 & 3 \\
\hline KESAMAPTAAN & 3 & 0 & 2 & 1 & 0 & 4 \\
\hline KESEHATAN & 4 & 3 & 4 & 3 & 1 & 5 \\
\hline PERFORMANCE & 0 & 0 & 0 & 0 & 0 & 1 \\
\hline
\end{tabular}

(Source: Data processed by Microsoft Excel)

Rounding numbers of Geometric Mean matrix which is the input data in the software Superdecision.

Once the data comparison between the cluster and the nodes of the existing models in superdecision program has filled everything, then we can know the unweighted supermatrix, weighted supermatrix, limit matrix, and priorities. 


\begin{tabular}{|c|c|c|c|}
\hline \multicolumn{4}{|c|}{ Here are the priorities. } \\
\hline Icon & Name & lized by Cluster [ & Limiting \\
\hline No Icon & 1.1 WORK DIRECTION & 0.07031 & 0.012360 \\
\hline No Icon & 1.2 LEADERSHIP & 0.30190 & 0.053072 \\
\hline No Icon & 1.3 ACTIVITY & 0.09943 & 0.017479 \\
\hline No Icon & 1.4 SOCIAL NATURE & 0.07976 & 0.014021 \\
\hline No Icon & 1.5 WORK STYLE & 0.18116 & 0.031847 \\
\hline No Icon & 1.6 TEMPERAMENT & 0.21742 & 0.038221 \\
\hline No Icon & 1.7 FOLLOWERSHIP & 0.05004 & 0.008796 \\
\hline No Icon & 2.1 KEMATRAAN & 0.13946 & 0.028410 \\
\hline No Icon & 2.2 PROFESI & 0.58243 & 0.118647 \\
\hline No Icon & 2.3 KESELAMATAN KERJA & 0.27811 & 0.056653 \\
\hline No Icon & 3.1 PENGASUHAN & 0.26260 & 0.030433 \\
\hline No Icon & 3.2 KOMUNIKASI & 0.47002 & 0.054472 \\
\hline No Icon & 3.3 BAHASA INGGRIS & 0.07752 & 0.008984 \\
\hline No Icon & 3.4 TEHNOLOGI INFORMASI & 0.18986 & 0.022003 \\
\hline No Icon & 4.1 KESEHATAN FISIK & 0.48850 & 0.178482 \\
\hline No Icon & 4.2 KESEHATAN JIWA & 0.51150 & 0.186888 \\
\hline No Icon & 5.1 BATEREI A & 0.66667 & 0.050680 \\
\hline No Icon & 5.2 BATEREI B & 0.33333 & 0.025340 \\
\hline No Icon & 6.1 KONDITE & 1.00000 & 0.06321 \\
\hline
\end{tabular}

Fig.4 Priorities of sub-criteria

From the results of fig 4 in mind the five subcriteria which have the greatest weight is the Mental Health (0.186888), and Physical Health (0.178482), Profession (0.118647), the efficiency report (0.063211) and Safety (0.056653). After learning weight of each sub-criteria, then the weight of each criterion can also be known. How to determine the weights of the criteria is to add weights of subcriteria for each individual criterionPriorities known five sub-criteria which have the greatest weight is the Mental Health (0.186888), and Physical Health (0.178482), Profession (0.118647), the efficiency report (0.063211) and Safety (0.056653). After knowing the weight of each sub-criteria, then the weight of each criterion can also be known. How to determine the weights of the criteria is to add weights of sub-criteria for each individual criterion.

Table 6. Weight Criteria

\begin{tabular}{|c|l|l|}
\hline NO & \multicolumn{1}{|c|}{ Criteria } & \multicolumn{1}{c|}{ Score } \\
\hline 1. & PAPI personality & 0,175796 \\
\hline 2. & Knowledge & 0,20371 \\
\hline 3. & Skill & 0,115892 \\
\hline 4. & Health ${ }^{*}$ & 0,36537 \\
\hline 5. & Phisic test & 0,07602 \\
\hline 6. & Performance & 0,063211 \\
\hline
\end{tabular}

\subsection{Assessment with PAPI method Kostick, DEMATEL ANP}

After obtaining weights from each of the subcriteria, an assessment scale was designed to determine the AAL Battalion Commander. The proposed rating scale is based on the Rating Scales assessment method (Primayantha, 2013) and Kostick for PAPI assessment using appropriate assessment scale psychological aspect which is the ratio between the sub-criteria based on three areas Kostick PAPI can be seen in the following:

Table 7. Rating Scales assessment

\begin{tabular}{|c|c|c|}
\hline No & Scoring scale & Mark \\
\hline \multicolumn{3}{|c|}{ Health Assessment Scale } \\
\hline 1 & 75 & Stakes I \\
\hline 2 & 65 & Stakes II \\
\hline 3 & 55 & Stakes IIP \\
\hline 4 & 45 & Stakes III \\
\hline 5 & 35 & Stakes IIIP \\
\hline 6 & 25 & Stakes IV \\
\hline 7 & 15 & Stakes IVP \\
\hline \multicolumn{3}{|c|}{ Scale Assessment of Physical Phisic test } \\
\hline 1 & $81-100$ & Very well \\
\hline 2 & $61-80$ & Well \\
\hline 3 & $41-60$ & Less \\
\hline 4 & $0-20$ & Very little \\
\hline \multicolumn{3}{|c|}{ Skills Assessment Scale } \\
\hline 1 & $81-100$ & B (Good) \\
\hline 2 & $61-80$ & C (Enough) \\
\hline 3 & $41-60$ & K-1 (Calculated) \\
\hline 4 & $0-20$ & K-2 (Not Graduated) \\
\hline \multicolumn{3}{|c|}{ Knowledge Capability Assessment Scale } \\
\hline 1 & $81-100$ & B (Good) \\
\hline 2 & $61-80$ & C (Enough) \\
\hline 3 & $41-60$ & K-1 (Calculated) \\
\hline 4 & $0-20$ & K-2 (Not Graduated) \\
\hline \multicolumn{3}{|c|}{ Performance scale } \\
\hline 1 & $81-100$ & B (Good) \\
\hline 2 & $61-80$ & C (Enough) \\
\hline 3 & $41-60$ & K-1 (Calculated) \\
\hline 4 & $0-20$ & K-2 (Not Graduated) \\
\hline
\end{tabular}

Table 8. PAPI assessment Kostick

\begin{tabular}{|c|l|l|}
\hline Ranking & Area & \multicolumn{1}{c|}{ Mark } \\
\hline 1. & & Optimal Area \\
\hline 2. & & Acceptable Area \\
\hline 3. & & Area for Development \\
\hline
\end{tabular}

Source table: (Primayantha, 2013) 
After the test against three candidates AAL Battalion Commander and the data obtained test results include the results of tests PAPI Kostick,
Knowledge, Skills, Health, Phisic test, Performance as follows:

Tabel 9. Kostick PAPI Test Results

\begin{tabular}{|l|c|c|c|c|c|c|c|c|c|c|c|c|c|c|c|c|c|c|c|c|}
\hline Aspect & G & L & I & T & V & S & R & D & C & E & N & A & P & X & B & O & Z & K & F & W \\
\hline Value of Candidate 1 & 4 & 4 & 5 & 5 & 5 & 5 & 4 & 4 & 2 & 6 & 5 & 7 & 6 & 4 & 3 & 3 & 4 & 4 & 3 & 5 \\
\hline Value of Candidate 2 & 4 & 5 & 4 & 3 & 5 & 6 & 4 & 4 & 8 & 1 & 3 & 7 & 6 & 4 & 3 & 3 & 4 & 5 & 3 & 4 \\
\hline Value of Candidate 3 & 5 & 6 & 5 & 5 & 5 & 6 & 7 & 2 & 7 & 7 & 6 & 6 & 3 & 5 & 4 & 6 & 5 & 5 & 5 & 1 \\
\hline
\end{tabular}

(Source: processed data)

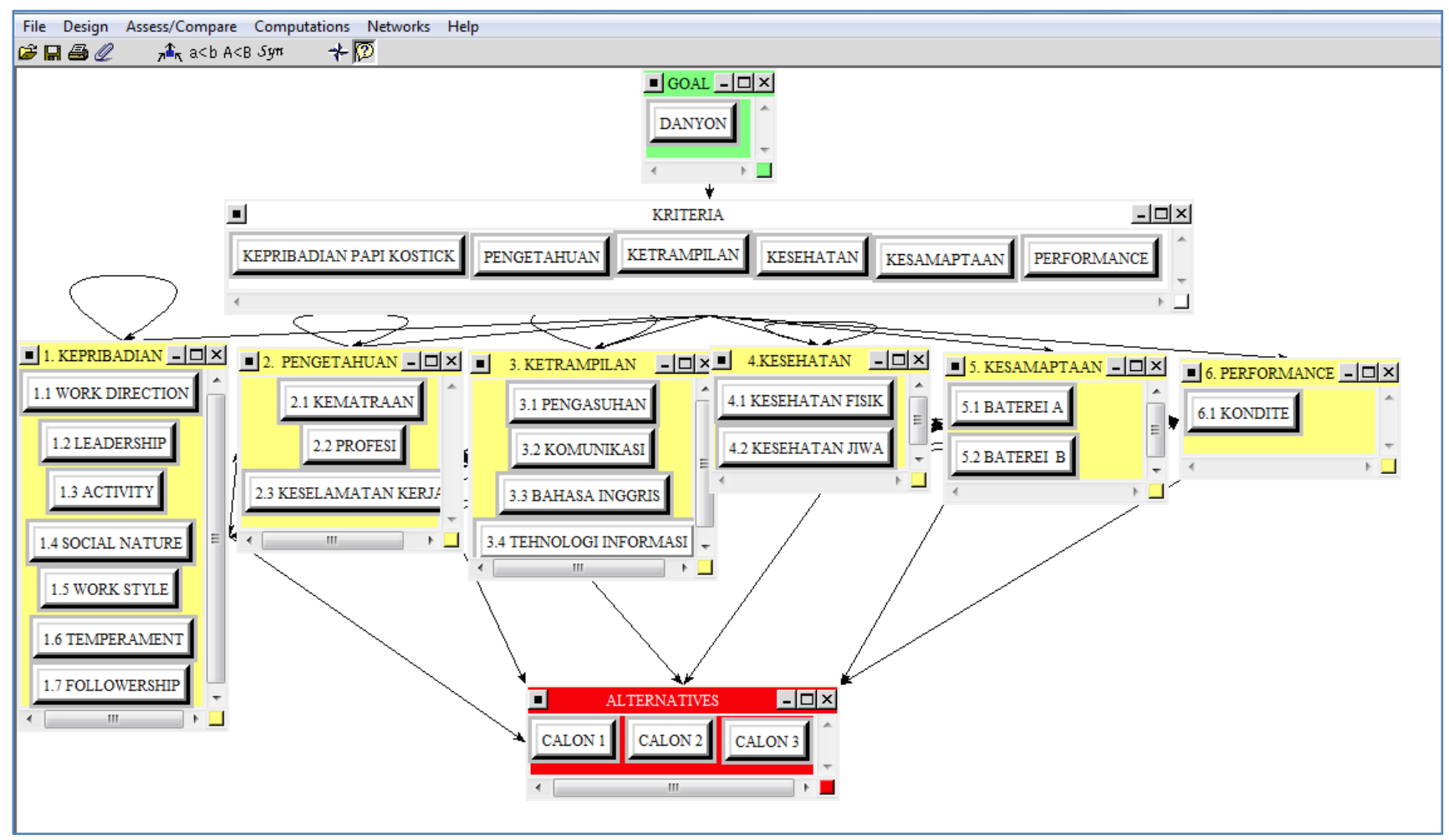

Fig.5 ANP models with alternative

Table 10. Other Sub-Criteria Test Results

\begin{tabular}{|l|l|l|l|l|}
\hline Subcriteria & $\begin{array}{l}\text { Candidate } \\
\mathbf{1}\end{array}$ & $\begin{array}{c}\text { Candidate } \\
\mathbf{2}\end{array}$ & $\begin{array}{c}\text { Candidate } \\
\mathbf{3}\end{array}$ & Ranking \\
\hline Dimensionality & K-1 & B & BS & $3,2,1$ \\
\hline Profession & C & C & BS & $3,1=2$ \\
\hline Work Case & BS & BS & BS & $1=2=3$ \\
\hline Parenting & C & B & B & $2=3,1$ \\
\hline Communication & B & B & B & $1=2=3$ \\
\hline English & K-1 & C & B & $3,2,1$ \\
\hline Teki Inf & C & C & C & $1=2=3$ \\
\hline Physical health & Stakes 2 & Stakes 2 & Stakes 1 & $3,1=2$ \\
\hline Mental health & Stakes 1 & Stakes 1 & Stakes 1 & $1=2=3$ \\
\hline Battery A & B & BS & BS & $2=3,1$ \\
\hline Battery B & K & B & BS & $3,2,1$ \\
\hline Konduite & B & BS & BS & $2=3,1$ \\
\hline
\end{tabular}

Rank the data obtained, it is used to fill in the pairwise comparisons Superdecision program according to the model is in Figure 6. We demonstrated pairwise comparisons on the nodes 
in the cluster Work Direction Alternatives to rank order that prospective 3 , candidate 1 , and 2 candidates.

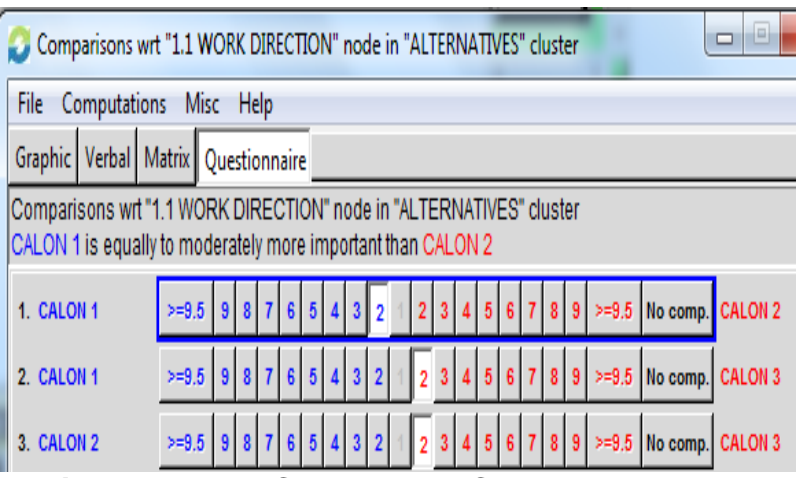

Fig.6 Pairwise Comparison Cluster Node Work Direction at Alternatives in)

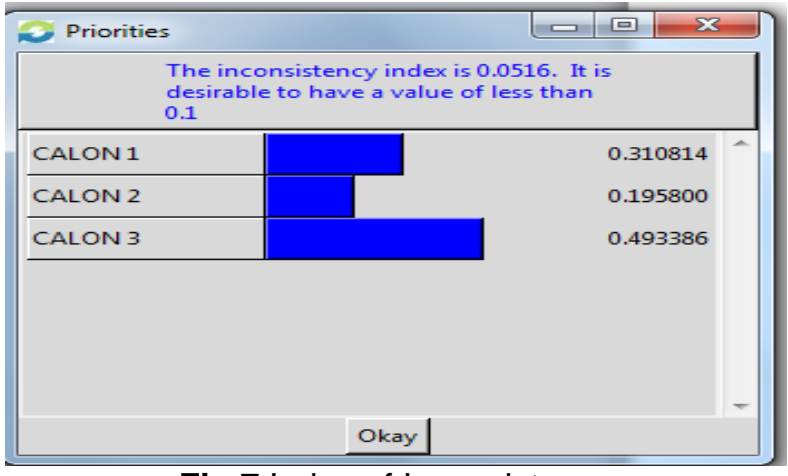

Fig.7 Index of Inconsistency

(Source : Data is processed with Super Decision)

Then put all the data in the software Superdecision rank, then the software is working on all phases of the ANP method by running synthesize, which contains among other alternative weighting value as seen red circled values in Fig 8 .

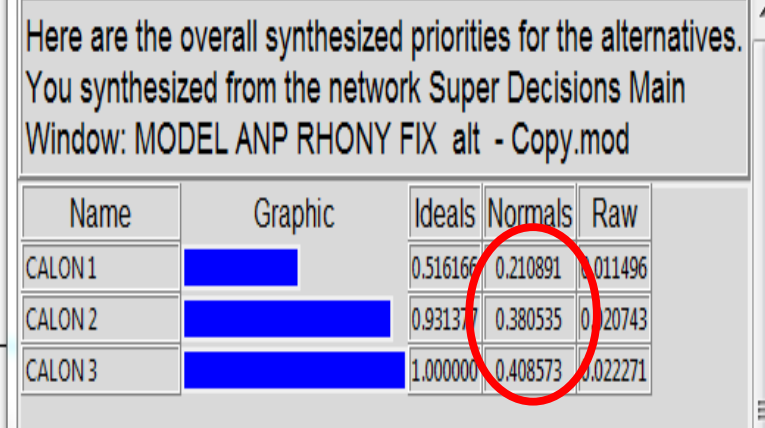

Fig.8 Alternative Weight Value

\subsection{Sensitivity analysis}

In this study, a sensitivity analysis is carried out by using a software Superdecisions is by changing the value of the node weights on alternative and tested.

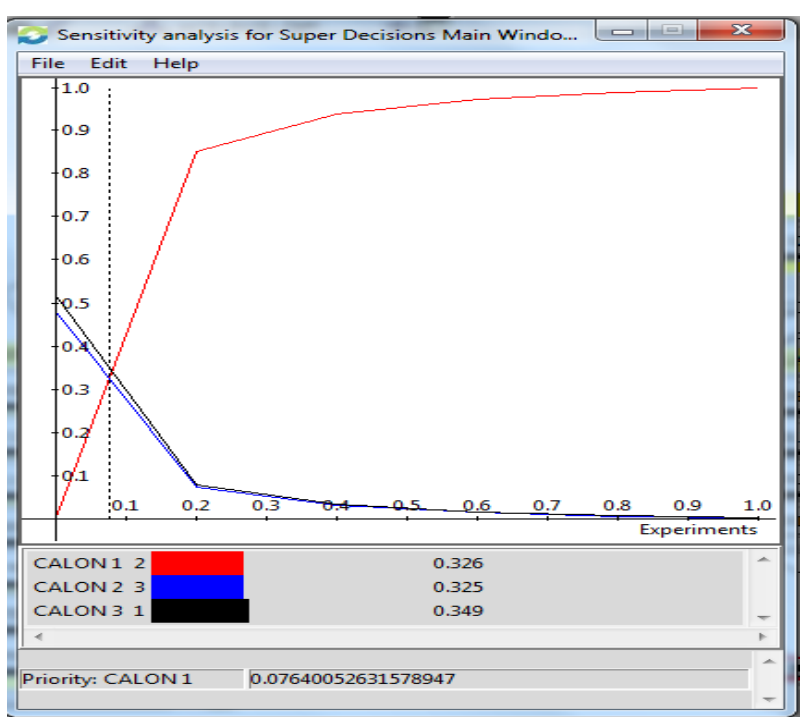

Fig.9 Sensitivity Analysis Alternative Candidate 1

In this sensitivity analysis will be known by making changes to the weight value or nodes that tested alternative will affect the results of ranking the original or not. Whenever there is a point where a change in rank / priority then the point is called the critical point an alternative or node.

The results of the sensitivity analysis of all nodes that can not lead to changes in rank / priority of alternatives, proving that this model is robust and unaffected by changes

\subsection{Building a computer-based system.}

To speed up the process in selecting candidates Lt assessment and decision making then built a computer-based system. By incorporating the results of tests of the candidates who will be selected based on Rating Scales, then the system will automatically multiplies with each percentage of the weight. 


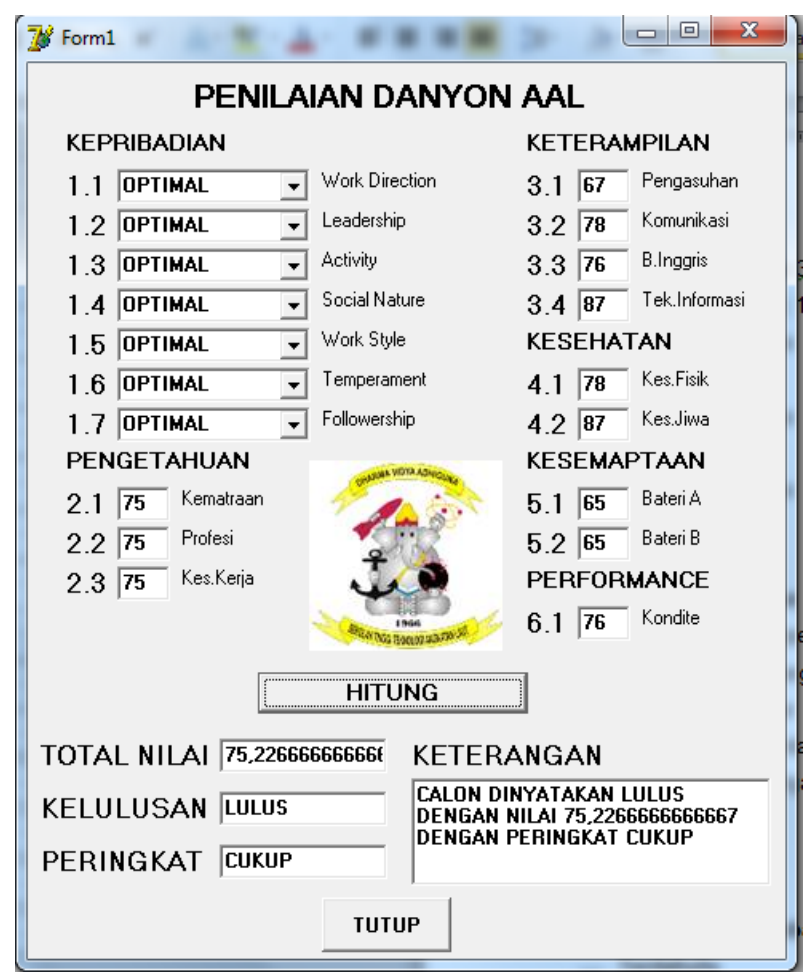

Fig.10 Computer based assessment system

\section{CONCLUSION}

From the results of data collection and processing, analysis and interpretation of the data processing has been done, then the conclusion can be drawn in this thesis are:

Sub-criteria soft competencies / skills factor are a total of 11 sub-criteria of the total sub-criteria which amounted to 19 sub-criteria such as Work Direction (Direction of Work), Leadership (Leadership), Activity (Activity), Social Nature (Social Behavior), Work Style (Style works), Temperament (Level Emotion), Followership (adherence to rules), Care, Communication, Mental Health, and Konduite have a total weight of 0.5108 or $51.08 \%$. While 8 other factors such as dimensionality, Professional, Safety, English, Information Technology, Physical Health, Batteries $A$, and Batteries $B$ which is subcriteria hard competency has a total weight of 0.4892 or $48.92 \%$.

That the selection of candidates scoring system AAL Battalion Commander objective is to include criteria such as PAPI Personality Kostick, Knowledge, Skills, Health, Phisic test, Performance.
That to build a computer-based system that can speed up the process in selecting candidates $\mathrm{Lt}$ assessment and decision making leaders of the Navy.

The suggestions can be presented in this thesis are: Suggestions for decision makers is to pay attention and use a soft criteria of competence (skills) as one of the selection test material position within the Navy. And the model of this study can be one of the alternative methods of assessment.. In order for the results of this study continue to be developed to analyze and determine the criteria and sub-criteria within the entire post of the Navy. For subsequent researchers who are interested in similar research can develop it by building a computerized system in the form of a web in the selection of valuation office.

\section{REFERENCES}

Commander of Indonesian Army Regulation Number / 138 / XII / 2011 dated December 14, 2011.

Hetharia, Dorina. 2009. Application of Fuzzy Analytic Hierarchy Process in Multi Attribute Failure Mode Analysis Method to Identify Causes of Potential Failures in Production Processes, TI ITS.

Hussey, J. and Hussey, R. 1997. Business Research: A Practical Guide for Undergraduate and Postgraduate Students, Macmillan Business, London.

Indratmo, Astria. 2013. Development Model Development Strategy in the Marketing Framework of the Madura Area Using the Multi Criteria Decision Making and Value Chain Approach, Postgraduate ITS Industrial Engineering.

Lin, Chi-Jen, dan Wu, Wei-Wen. 2004, A Fuzzy Extension of the DEMATEL Method for Group Decision-Making, Institute Engineering and Management Ta Hwa Institute of Technology Taiwan.

Moekijat. 1998. Job Analysis. Mandar Madju, Bandung. 
Maulana, Primayantha. 2013. Analysis and Determination of the Position of the Commander of KRI Diponegoro (Sigma) based on Papi Kostick Dematel Fuzzy ANP's personality method.STTAL

Nugraha, Riandy Rahman. 2012. Application of Fuzzy Logic to Calculate Daily Allowances, School of Electrical and Information Technology ITB.

Prahastuti, Widya dkk .2013. Development of Chemo Learning Tools for Entrepreneurship redox reaction materials for grade $X$ high school students, Innovative Journal of Curriculum and Educational Technology.

Priadi, Dedi. 2009. Company Manager Selection Based on Personality And Preference Personality Test (PAPI) and Analytic Hierarchy Process (AHP), Post-Graduate TMI ITB.

Puspitasari, Annisa dan Ciptomulyono, Udisubekti. 2011. Application of the Zero-One Goal Programming Model, DEMATEL, \& ANP for optimization of marketing strategy selection, TI ITS.

Rokhimawan, M. Agung. 2012. Development of Soft Skills for Teachers in Science Learning in Elementary / MI Future with National Character Vision, Journal of UIN Sunan Kalijaga Yogyakarta Vol. 4 No.1.
Sanz, Jesus, et.al. 2006. Self-Assesment of Need and Behavior Patters at Work: Psychometric Properties of The Personality and Preference Inventory-Normative (PAPI-N). Elsevier.

Solikin, Fajar. 2011. Fuzzy Logic Application in Optimizing Goods Production Using the Mamdani Method and Sugeno Method, Faculty of Mathematics and Natural Sciences, Yogyakarta State University.

Susilo, Hendri. 2009. Designing Assessment System for Prospective Crews Using Analytic Network Process Approach, STTAL.

Sutikno. 2006. Comparison of the Mamdani Rules Defuzzification Method in the Fuzzy Logic Control System (Case Study in Setting DC Motor Speed).TE Undip.

Tri Ariyanto, Agus. 2011. Selection of Anti Submarine Helicopters as Target Reporting Unit Helicopters on KRI Ahmad Yani Class Post Yakhont Missile Installation Using Analytic Network Process (ANP) Method,STTAL.

Utari, Lis .2011. Design and Build a Middle School Student Value Database Choosing a Vehicle (Car) with the Analytic Hierarchy Process (AHP) and Superdecision Method, Scientific Journal of Technology and Information Vol.2.

2013. Training on Search and Development of Navy Competency Soft Competency officers. Dispsial, Surabaya 